\title{
Um olhar sobre a educação escolar indígena no século XXI
}

\author{
Hellen Cristina Picanço Simas* \\ Cassandra Augusta Rodrigues Nascimento**
}

\section{BANIWA, Gersem. EDUCAÇÃO ESCOLAR INDÍGENA NO}

SÉCULO XXI: encantos e desencantos. - 1. ed. - Rio de Janeiro: Mórula, Laced, 2019.

Credenciais do autor: O autor Gersem José dos Santos Luciano Baniwa é indígena da etnia Baniwa, possui vasta publicação em temas relacionados aos povos indígenas do Brasil e, especificamente, sobre a educação escolar indígena e a educação indígena. Foi Secretário de Educação do município de São Gabriel da Cachoeira (AM), dirigente de organizações indígenas. Atuou, em 2009, como coordenador geral de Educação Escolar Indígena na extinta Secretaria de Educação Continuada (SECAD) e organizou, no mesmo ano, a I Conferência Nacional de Educação Escolar Indígena. Graduado em Filosofia, foi o primeiro indígena a ter o título de doutor em Antropologia no Brasil. Atualmente é professor Adjunto do Departamento de Educação Escolar Indígena da Faculdade de Educação da Universidade Federal do Amazonas. Conselheiro no Conselho Nacional de Educação, períodos de 2006-2008 e de 2016-2020.

Organização da obra: o livro é constituído por 295 páginas e organizado em oito capítulos, que abordam a ideia de uma educação indígena intercultural, bilíngue e diferenciada nos sistemas

* Universidade Federal do Amazonas. Professora do programa de Pós-Graduação em Educação da Universidade Federal do Amazonas.

india.parintintins@gmail.com

** Universidade Federal do Amazonas. Mestranda do programa de Pós-Graduação em Educação da Universidade Federal do Amazonas.

cassandraaugusta@gmail.com 
educacionais do Brasil no decorrer do século XXI. O subtítulo do livro faz referência às conquistas e aos problemas relacionados às políticas de educação escolar indígena vivenciados pelos povos nativos durante o período de 2003 a 2019. O autor acredita que a estruturação de uma política de inclusão para os povos indígenas está atrelada ao reconhecimento dos saberes originários, à diversidade e à diferença, contribuindo, assim, para a consolidação de políticas públicas para a educação escolar indígena.

Síntese da obra: No capítulo inicial, há uma abordagem sobre a educação escolar indígena no Brasil no final do século XX, apontando para o interesse do Estado em dizimar os povos originários. Ao longo dos 488 anos de colonização, as elites coloniais foram responsáveis pelo desaparecimento de vários povos, culturas e línguas. Esse processo acirra as lutas contra a ditatura militar que retira alguns povos indígenas de suas terras.

O segundo capítulo trata de extensas reflexões sobre educação e povos indígenas sob a perspectiva dos debates interculturais. Baniwa estrutura o capítulo analisando a educação, a instituição escolar, a escola indígena intercultural, o papel das línguas nas cosmologias indígenas e os (des) caminhos da inclusão dos povos indígenas. Apesar do extenso diálogo, o objetivo do autor é demonstrar que, somente com o protagonismo e a autonomia indígena nos processos educativos e administrativos, se efetivará os princípios interculturais. Na página 65, o autor levanta uma grande questão que precisa ser pensada: "como garantir uma educação diferenciada aos indígenas em todas as fases de seu percurso escolar e universitário?

O terceiro capítulo busca analisar a trajetória dos direitos indígenas e das políticas indígenas na era petista. Destaca a esperança dos povos indígenas com a eleição dos governos petistas do presidente da República Luiz Inácio Lula da Silva e da presidenta Dilma Rousseff, respectivamente. De modo geral, as expectativas eram gigantescas, considerando que as lideranças indígenas participaram efetivamente da equipe de transição do Governo. A sensação 
do autor é que se perdeu uma grande oportunidade para mudar o Brasil, a história e o cenário dos povos indígenas.

No quarto capítulo, Baniwa faz um balanço das políticas de educação escolar na era PT. Dentre as boas iniciativas dos governos petistas, destacam-se: a criação da Secretaria de Educação Continuada, Alfabetização e Diversidade (SECAD), em 2004; a criação e a ampliação gradual do Programa de Formação Inicial de Professores Indígenas nos níveis secundário (com o Magistério Indígena) e superior (com a Licenciatura Intercultural/PROLIND); a adoção de um conjunto de medidas para facilitar e possibilitar o acesso de indígenas ao ensino superior; a realização da I Conferência Nacional de Educação Escolar Indígena (2009) e, já no Governo Dilma, em 2014, a criação do Programa Saberes Indígenas na Escola (PSIE).

O quinto capítulo do livro centra-se no debate das políticas de ações afirmativas para garantir o acesso dos povos indígenas ao ensino superior e a permanência deles na universidade. Nesta perspectiva, a Lei 12.711/2012 estabelece a obrigatoriedade de reserva de vagas nas Universidades e Institutos Federais.

No sexto capítulo, o autor reflete sobre a formação indígena e os desafios da participação para alcançar a autonomia etnopolítica. Mesmo diante do reconhecimento dos direitos de autonomia étnica e cultural dos povos indígenas pela Constituição Federal, é necessário lutar pelo reconhecimento do direito à diferença, permitindo a continuidade histórica dos povos originários. A conquista dos espaços de participação, representação e gestão pelo movimento indígena servem como processo de aprendizagem para o empoderamento e o controle social das políticas indigenistas.

No sétimo capítulo, Baniwa elenca o cenário de obscuridade do país e da política indigenista da era Pós-PT. Na verdade, percebe-se a decepção do autor ao descaso dos governos quanto aos direitos às terras originárias. Para o autor, repete-se o desrespeito aos povos indígenas, a demarcação de terras provoca gera grandes conflitos de forma mais acentuada no governo Temer, que adota uma postura anti-indígena, intervencionista e etnocêntrica. Em 
janeiro de 2019, toma posse o Presidente Jair Bolsonaro, que, na visão de Baniwa, traz de volta a ideia de "índios transitórios", ou seja, de que a população indígena do Brasil representa impedimento para o desenvolvimento do país.

O oitavo capítulo apresenta a análise da educação escolar indígena e as contrarreformas da educação brasileira. Nesse capítulo, o autor faz reflexões sobre os impactos, no campo educacional da Reforma do Ensino Médio e a criação da Base Nacional Comum Curricular (BNCC). Destaca, ainda, o grande retrocesso da Educação Escolar Indígena, na gestão do Presidente Jair Bolsonaro com a extinção da SECAD, da Coordenação Geral de Educação Escolar Indígena (CGEEI) e da Comissão Nacional de Educação Escolar Indígena (CNEEI).

A obra termina considerando que não é mérito julgar se a Reforma do Ensino Médio e a Base Nacional Comum Curricular, sejam boas ou não, se ajudarão ou atrapalharão. Baniwa fecha o seu texto, enfatizando, na página 292, que “os povos indígenas estão vigilantes, mobilizados, capacitados e determinados a assumir sua autonomia e protagonismo de vida, contra os quais, não há governo ou proposta que resista".

Quadro de referências do autor: as reflexões sobre as ações que foram realizadas pelos Governos em relação à educação escolar indígena partem da experiência do autor e de sua liderança indígena. Discute as questões a partir do olhar indígena, considerando a história e as lutas dos povos nativos de forma a tecer um confronto entre o que os indígenas esperavam e o que foi realizado nos Governos, ou seja, apresenta o olhar indígena com base na experiência pessoal versus o olhar não indígena expressos nas ações dos Governos. As leis e decretos brasileiros que versam sobre o tema em debate são o seu referencial teórico para respaldar suas análises.

Metodologia da autoria: o autor utilizou como método de abordagem o indutivo e como método de procedimento o histórico. Empregou a modalidade descritivo-analítica e utilizou-se da técnica observação. O livro é resultado da tese de doutorado do autor. 
Indicações do resenhista: o livro é de extrema importância para o campo educacional e para a formação de indígenas e não-indígenas. É indicada, principalmente, para graduados dos cursos de Licenciaturas, Pedagogia, Antropologia, História e Direito. Esta obra traz esclarecimentos a respeito de um conceito tão relevante: a educação escolar indígena brasileira e uma contribuição relevante para as discussões a respeito da educação escolar indígena no Brasil do século XXI. Assim, vem minimizar a lacuna da falta de produção de literatura científica a respeito do tema, tão esquecido nas produções acadêmicas educacionais atuais. 